\title{
СТРАТЕГІЧНІ ПІДХОДИ ЩОДО ОПЕРАТИВНОГО УПРАВЛІННЯ ПІДПРИЄМСТВ ТВАРИННИЦТВА В КОНТЕКСТІ ЇХ РЕНОВАЦІї
}

\author{
Лівінський Анатолій Іванович \\ кандидат сільськогосподарських наук, доцент \\ Одеський державний аграрний університет (м.Одеса, Україна) \\ ORCID: 0000-0002-1381-5714 \\ 2606147@ukr.net
}

Автор розглядає актуальність процесів модернізації та інноваційного оновлення аграрної ссрери в контексті реноваційного розвитку підприємств тваринництва. В статті визначені стратегічні підходи щодо оперативного управління підприємствами тваринництва в контексті реновації галузі та ї ролі в національній економіці України. Доведено, що формалізація господарських рішень у типових ситуаціях і способів прийняттяя управлінських рішень вимагає чіткого визначення понять «незапланована виробнича ситуація» й «типова ситуація» стосовно технологічних операцій і процесів у аграрному виробництві. Визначено критерії оцінки якості оперативних рішень на підприємствах тваринництва

Ключові слова: стратегічні підходи, підприємства тваринництва, оперативне управління.

DOI: https://doi.org/10.32845/bsnau.2019.1.8

Постановка проблеми: В сучасних умовах ризикованої кон'юнктури світових ринків агропродовольчої продукції вітчизняні підприємства тваринництва відчувають економічну нестабільність та потребують гнучких оперативних рішень в контексті реновації галузі та забезпечення реалізації своїх стратегічних завдань. 3 метою розробки дієвої стратегії оперативного управління на вітчизняних підприємствах тваринництва та якісної економічної реакції на виклики глобалізаційних процесів необхідно визначити принципові підходи щодо її успішної реалізації.

Аналіз останніх досліджень та публікацій: Процеси розробки стратегій в аграрній сфері в напрямку удосконалення оперативних управлінських рішень щодо їх реновації досліджують відомі вітчизняні вчені: Дерій Ж.В, Давидюк О.О., Данько Ю.І., Саблук П.Т., Малік М.Й., Марчук Л.Л, Маркіна І.А., Гришова І.Ю., Ніколюк О.В., Дяченко О.П., Стоянова-Коваль С.С., Шабатура Т.С., Шестаковська Т.Л., Яців І.Б.[1-10]

Результати досліджень: Перспективними напрямами досліджень по вдосконаленню оперативного управління реновації підприємств тваринництва в аграрному виробництві базуються на визначенні принципових підходів,які можуть бути класифіковані таким чином:

Розглядаючи перспективи використання досягнень науки для вдосконалення оперативного управління в тваринництві, необхідно насамперед чітко, із сучасних позицій сформулювати зміст і основні визначення, які стосуються самого поняття «оперативне управління». Для цього необхідно:

І. Дослідити інформаційні аспекти оперативного управління в тваринництві.

1. Розробити критерії оцінки оперативної інформації як специфічного виду виробничих ресурсів. Відомо, що для оперативного планування, оперативного аналізу, формування й прийняття варіантів оперативних рішень необхідна інфоормація про наявність, перспективи одержання, способи раціонального розподілу й перерозподілу матеріальних і трудових ресурсів, про соціологічні аспекти проблеми й т.д. ІНакше кажучи, виникає потреба в інформаційному забезпеченні оперативного управління як своєрідного виробничого процесу, який регламентується певною технологією, де ін- формаційне забезпечення може розглядатись як специфічний вид виробничих ресурсів. Цей вид ресурсів забезпечує не лише необхідну якість управлінських рішень, але й саму можливість оперативного управління виробництвом. Для визначення вимог до інфоормаційного забезпечення і його формування в конкретних виробничих ситуаціях необхідно розробити чіткі критерії кількісної і якісної оцінки інформації як специфічного виду виробничих ресурсів.

2. Дослідити динаміку морального старіння оперативної інформації та її взаємозв'язок із зміною виробничих структур і номенклатури тваринницьких підрозділів. У процесі розвитку АПВ змінюються спеціалізація, організаційна структура, внутрішні й зовнішні зв'язки, обсяг і номенклатура продукції, що випускається й переробляється, як у виробничих, так й в управлінських підрозділах. Одночасно змінюється відповідно й інформаційне забезпечення, яке необхідне для процесу оперативного управління вказаними підрозділами. Іншими словами, із зміною умов виробництва частина інформації застаріває, стає непотрібною і її слід виключати з інфоормаційного забезпечення, а замість неї вводити нову. Дослідження динаміки застарівання оперативної інформації й заміни її новою - одна з функцій оперативного управління як процесу. Кількісні та якісні оцінки цих змін можуть використовуватись у процесі вдосконалення організації оперативного управління в тваринництві.

3. Розробити принципи формування структур управління й штатної чисельності управлінського персоналу в тваринницьких підрозділах. 3 цією метою необхідно дослідити існуючі потоки оперативної інформації: виявити інтенсивність, номенклатуру й адресність показників вертикальних і горизонтальних потоків оперативної інформації на тих ієрархічних рівнях управління, що нас цікавлять, провести аналіз використання цих потоків (ким і як використовується ця інфрормація), визначити необхідну номенклатуру показників, оцінити обсяг робіт (витрати праці) при обробці вхідної інформації (запити, інформація про прийняті управлінські рішення) і на основі одержаних оцінок витрат праці розробити принципи формування структури та штатної чисельності управлінського персоналу в тваринницьких підрозділах.

4. Розробити методологічні засади формалізації про- 
цесу прийняття рішень в оперативному управлінні у тваринництві із застосуванням сучасних інформаційних технологій. Для використання останніх при оперативному управлінні сільськогосподарським виробництвом необхідно формалізувати технологічний процес прийняття оперативних рішень визначити місце, час й величину управлінських впливів, а також передбачити оцінку результатів цих впливів на кінцевий результат виробництва. Сюди входять і розробка методик підготовки вихідної інформації, створення програмного забезпечення, які відповідають вимогам оперативного управління на різних ієрархічних рівнях АПВ.

II. Сформулювати концепцію оперативності управління на різних рівнях системи тваринницького виробництва в умовах його технологічної реновації з урахуванням вимог інноваційного розвитку. Оперативне управління за своєю суттю покликане контролювати й забезпечувати виконання виробничих планів, а в разі необхідності й оперативно коригувати їх залежно від ситуації, що склалася. Чим вищий ієрархічний рівень управління, тим більш укрупнені показники планів його фрахівці контролюють й, відповідно, приймають необхідні управлінські рішення. Отже, прийняті рішення діють (мають чинність) на триваліших інтервалах часу. Таким чином, оперативність (гранично припустима швидкість) виконання цих рішень для різних рівнів управління буде різною. Сьогодні в системі АПВ немає чітких розмежувань у понятті «оперативний план» для різних рівнів управління: для підприємства, району, області, країни в цілому. Немає також і чіткого уявлення про те, на яких рівнях управління слід займатись декадними, місячними або квартальними й т.п. виробничими планами. Це питання виникло у зв'язку з розробкою автоматизованих систем управління сільськогосподарським виробництвом, виявленням і класифікацією завдань, при розв'язанні яких можна використовувати сучасні математичні методи й програмні засоби.

3 іншого боку, в умовах технологічної реновації аграрного виробництві, у зв'язку із розвитком міжгосподарських зв'язків, формуванням інтегрованих підприємств і організацій, із створенням агропромислових об'єднань, із зростанням кількості і з ускладненням виробничих зв'язків всередині підприємств і об'єднань питання, пов'язані з використанням досягнень науки в аграрному виробництві, набувають особливої актуальності. У цих умовах необхідно чітко сформулювати концепцію оперативності управління аграрним виробництвом, розробити методику і провести відповідні дослідження з тим, щоб однозначно в масштабах АПВ розв'язувати завдання, які відноситься до завдань оперативного управління. Це має значно поліпшити впровадження досягнень науки в управлінні тваринництвом.

III. Розробити й обґрунтувати методику визначення допустимого випередження при прийняті оперативних рішень у тваринницьких підрозділах.

При виборі варіанта оперативного рішення необхідно провести оцінку впливу кожного з можливих варіантів цих рішень на кінцевий результат функціонування керованого об'єкта або процесу і забезпечити вибір такого, що задовольняє заздалегідь визначені вимоги. Іншими словами, необхідно передбачити результати впливу будь-якого втручання на хід процесу, на розвиток певного явища, на функціонування виробничого об'єкта.

Людське мислення здатне навчитись передбаченню (прогнозуванню): людина, здійснюючи будь-якові дію, свідомо чи несвідомо попередньо оцінює її результат. У складних ситуаціях, коли на керований об'єкт діє велика кількість різних, у тому числі й випадкових факторів, доводиться вдаватися до науково обгрунтованих методів прогнозування, включаючи математичні моделі. Відомо, що точні прогнози вдається одержати лише в детермінованих системах. Високу точність прогнозів можна мати й для випадкових стаціонарних процесів, тобто таких, які описуються постійними ймовірнісними характеристиками. В усіх останніх випадках прогнози можуть бути тільки приблизними.

Із збільшенням часу випередження точність прогнозів знижується, так саме знижується і якість варіантів оперативних рішень, вибраних на основі цих прогнозів. Практично реальні виробничі процеси, особливо в аграрному виробництві, нестаціонарні - їх характеристики змінюються в часі. Таким чином, проблема вибору допустимого випередження при прийнятті оперативних рішень у науковому плані зводиться до вибору (розробки) методів, які дають змогу збільшувати час випередження при прогнозуванні в межах допустимих змін якості оперативних рішень.

IV. Визначити методичні підходи до підготовки й впровадження типових управлінських рішень у незапланованих господарських ситуаціях.

Створення агропромислових об'єднань, переведення їх на промислову основу, укрупнення й спеціалізація аграрних підприємств призвело до збільшення кількості та підвищення складності виробничих ситуацій, які виникають. Практично керівники й спеціалісти в аграрних підприємствах внаслідок інформаційного й організаційного перевантаження не в змозі сприймати й оцінювати всю сукупність варіантів оперативних управлінських рішень, які виникають у конкретних виробничих ситуаціях, і своєчасно, з урахуванням вимог системного підходу знаходити найбільш раціональний варіант. Причина такого стану пояснюється незадовільним використанням у господарській практиці нагромаджених наукових знань і практичного досвіду при прийнятті оперативних управлінських рішень, а також відсутністю інформаційно-довідкової літератури, яка узагальнює ці знання й досвід. Для усунення цих недоліків доцільно провести аналіз, узагальнення й формалізацію теоретичних й емпіричних досліджень у галузі оперативного управління, впорядковувати й типізувати факторні й міжфакторні зв'язки, які визначають продуктивність аграрного виробництва. Необхідно виявити виробничі ситуації, у яких приймались незаплановані оперативні управлінські рішення, згрупувати й класифікувати їх за типами, а також за причинами їх використання.

Формалізація господарських рішень у типових ситуаціях і способів прийняття управлінських рішень вимагає чіткого визначення понять «незапланована виробнича ситуація» й «типова ситуація» стосовно технологічних операцій і процесів у аграрному виробництві. Слід розробити методики ідентифікації конкретних незапланованих виробничих ситуацій, які зустрічаються в практиці з типовими ситуаціями. Це дасть змогу значно скоротити номенклатуру типових ситуацій і спростити процес прийняття рішень. Одночасно необхідно опрацювати способи коригування методів прийняття управлінських рішень в умовах зміни технології й організації виробництва, передбачити розумну універсалізацію алгоритмів рішень, які приймаються, можливість використання їх для широкого кола господарських ситуацій.

Вісник Сумського національного аграрного університету Серія «Економіка і менеджмент», випуск 1 (79), 2019 
Очевидно, що така універсалізація алгоритмів прийняття рішень призведе до збільшення витрат часу на це порівняно із спеціалізованими алгоритмами, розробленими для окремих виробничих ситуацій. У зв'язку із цим «розумна універсалізація» означає розумний ступінь сповільнення роботи створюваних універсальних алгоритмів прийняття рішень у кожному конкретному виробничому процесі. Слід зазначити, що алгоритмізація методів прийняття управлінських рішень у типових ситуаціях передбачає можливість використання досвіду прийняття рішень широким колом керівників і фахівців різних ієрархічних рівнів управління не тільки в аграрному виробництві, але й в інших галузях економіки.

Б. Оперативне управління - це механізм забезпечення виконання стратегічних рішень із розвитку тваринництва. Оперативне управління в широкому розумінні цього терміну покликане здійснювати контроль й аналіз виконання планово-виробничої й організаційно-господарської діяльності підрозділів агропромислового виробництва, приймати конкретні управлінські рішення, які забезпечують виконання кінцевих показників діяльності цих підрозділів або обґрунтоване їх коригування. Практично це заключна ланка в сфері організації управління тваринницьким виробництвом - ланка, яка забезпечує досягнення високих кінцевих результатів функціонування тваринницького виробництва й об'єктів, які входять до його складу. При розгляді оперативного управління під вказаним кутом зору виникає ряд питань і проблем, для розв'язання яких необхідно провести такі дослідження:

1. Розкрити основний зміст оперативного управління як кінцевої ланки управління тваринницьким виробництвом, що безпосередньо забезпечує його дієвість. Тут необхідно показати, як у структурі тваринницького виробництва на різних його ієрархічних рівнях здійснюється оперативне управління діяльністю різних організацій і підрозділів, що входять у систему АПВ, як воно впливає на кінцеві результати цієї діяльності, показати, як впливають оперативні рішення, прийняті на вищих ієрархічних рівнях структури АПВ, на результати виробничої діяльності в підрозділах і т.д.

2. Визначити критерії оцінки якості оперативних рішень. Насамперед, необхідно обґрунтувати й сформулювати саме поняття якості оперативних рішень, загальні вимоги до них і зв'язати їх з кінцевим продуктом, потім створити систему критеріїв оцінки якості оперативних рішень і тільки після цього розробити й експериментально перевірити методику розрахунку оцінок в умовах АПВ.

3. Розробити методичні підходи побудови імітаційних моделей технологічних процесів для застосування в оперативному управлінні тваринницьким виробництвом. Основи імітаційного моделювання в управлінні аграрним виробництвом нині розроблені стосовно низової ланки АПВ. Аналогічні розробки слід здійснити й для вищих ієрархічних рівнів АПВ, пов'язавши їх з уже відомими методами моделювання. Необхідно розробити практичні методи оптимізації оперативних рішень для об'єктів описаних стохастичними й детермінованими системними імітаційними моделями, використовуючи досвід, нагромаджений в інших галузях національного господарства.

4. Обґрунтувати методичні підходи до прогнозування оцінок кінцевої результативності технологічних процесів для застосування в системі оперативного управління тваринницьким виробництвом. 3 нашої точки зору, найбільш перспективно для цієї мети використовувати імітаційні структурно- функціональні моделі, які дають змогу одержувати не лише прогнозні оцінки результатів функціонування виробничих підрозділів як об'єктів управління, але й прогнози оцінок пофакторних недоборів кінцевої продукції. Викладені моделі, як правило, досить складні й тому їх використання в оперативному управлінні може викликати певні труднощі. У зв'язку із цим виникає необхідність у розробці методики побудови більш простих моделей. Параметри цих моделей повинні періодично коригуватися для різних виробничих ситуацій, пов'язаних із сезонними особливостями функціонування виробничих об'єктів, з удосконаленням технології виробництва, а також при зміні вимог до виробничого процесу. Створення таких моделей підвищить оперативність процесу прийняття управлінських рішень.

5. Розробити методичні підходи використання прогнозних оцінок кінцевої результативності технологічних процесів при оперативному управлінні тваринницьким виробництвом. 3 цією метою слід виявити завдання, які необхідно розв'язувати при оперативному управлінні на всіх рівнях виробництва, провести аналіз методів їх розв'язання й, при необхідності, знайти можливості вдосконалення цих методів шляхом використання прогнозних оцінок впливу організаційно-технологічних і погодних фракторів на кінцевий результат виробництва. Одним із шляхів практичного використання вказаних прогнозних оцінок $€$ одержання їх за допомогою згаданих вище моделей навчання.

Висновки: Для успішного впровадження у тваринництво й у аграрний сектор національного господарства взагалі типових управлінських рішень і спрощення користування ними в практиці оперативного управління необхідно розробляти спеціальні методики, довідники по прийняттю рішень у типових виробничих ситуаціях з наступною формалізацією й алгоритмізацією цих методик, створенням сучасних інформаційних систем, які видаватимуть потрібну інформацію у вигляді порад. До початку вказаних розробок необхідно попередньо створити відповідну методологію, яка спиратиметься на дослідження: принципів диференціації факторів продуктивності аграрного виробництва; методів сегментації (якісного розподілу) факторів продуктивності аграрного сектору економіки й формування сегментів типів (типових комбінацій фракторів); методів побудови й типізації внутрішніх зв'язків між факторами продуктивності в сегментах; методів типізації сегментів і способів їх перенесення на реальні технологічні операції; методів типізації агротехнічних й агрометеорологічних умов, які впливають на технологічні операції в аграрному виробництві (на його продуктивність); структуризація (визначення місця й значущості) та формалізація управлінських рішень за типами (факторів продуктивності й типовими умовами господарювання); методичних принципів типізації й формалізації прийняття управлінських рішень.

Викладені вище методологічні підходи вдосконалення оперативного управління у тваринництві не вичерпують можливостей використання досягнень аграрної економічної науки. Коло актуальних питань може бути розширене й уточнене в процесі проведення досліджень й апробації результатів їх експериментальної перевірки у виробничих умовах. По ряду згаданих проблем уже здійснюються дослідження, але по більшості з них вони навіть не плануються, на що має бути звернута особлива увага при плануванні розвитку аграрної науки.

Вісник Сумського національного аграрного університету Серія «Економіка і менеджмент», випуск 1 (79), 2019 


\section{Список літератури:}

1. Ніколюк, О. В, Лівінський А.І Стратегічний аспект формування регуляторної політики соціально-економічного розвитку аграрного виробництва [Текст]. Економічний аналіз: зб. наук. праць / Тернопільський національний економічний університет; редкол.: О. В. Ярощук (голов. ред.) та ін. - Тернопіль: Видавничо-поліграфічний центр Тернопільського національного економічного університету «Економічна думка», 2018. - Том 28. - № 1. - С. 303-310. - ISSN 1993-0259.

2. Ніколюк О.В., Галицький О.М Методологія інституціоналізації державного регулювання аграрного виробництва. Агросвіт. - 2017. - №13. - С. 24-28

3. Gryshova I. Yu., Shestakovska T. L., Glushko O. V. The economic measurement of convergence of institutional impact on the sustainability of development . Scientific Papers of the Institute of Legislation of the Verkhovna Rada of Ukraine. - 2017. - №4. - pp.75-80.

4. Гришова І.Ю. , Стоянова-Коваль С.С. Аналітичне забезпечення економічного розвитку підприємств з позицій інвестиційної привабливості. Проблеми і перспективи економіки та управління : науковий журнал / Черніг. нац. технол. ун-т. - Чернігів : Черніг. нац. технол. ун-т, 2015. - № 2 . - С. 195-204.

5. Гришова І. Ю., Стоянова-Коваль С. С. Інвестування стратегій інноваційного розвитку суб'єктів аграрної сфери України / Вісник Сумського національного аграрного університету серія «Економіка та менеджмент». - №4 (68). - 2016 - С.12-16

6. Дерій Ж.В., Галицький О.М. Стратегія удосконалення інноваційно-інвестиційної державної політики щодо розвитку аграрного виробництва в Україні Український журнал прикладної економіки. - 2017. - Том2. - № 4. - С.6-11.

7. Давидюк О. О., Марчук Л. Л. Організаційно-інституційні імперативи удосконалення державного регулювання захисту економічних інтересів в аграрній сфері. Інвестиції: практика та досвід. 2018. № 20. C. 23-28. DOI: 10.32702/2306$\underline{6814.2018 .20 .23}$

8. Марчук Л.Л Міжнародні методики оцінки конкурентоспроможності національної економіки в контексті економічної безпеки. // Економічний аналіз: зб. наук. праць / Тернопільський національний економічний університет; редкол.: О. В. Ярощук (голов. ред.) та ін. - Тернопіль: Видавничо-поліграфічний центр Тернопільського національного економічного університету «Економічна думка», 2017. - Том 27. - №4. - С. 311-317. - ISSN 1993-0259.

9. LivinskyA. (2018). Methodological aspects of forecasting the renovation development of livestock enterprises. Scientific Papers of the Legislation Institute of the Verkhovna Rada of Ukraine, (3), 57-64. Retrieved from https://instzak.com/index.php/journal/article/view/1590

10. Лівінський, А. І. Закордонний досвід регулювання діяльності аграрних виробників у контексті реновації вітчизняної аграрної економіки [Текст] / Анатолій Іванович Лівінський // Український журнал прикладної економіки. - 2017. - Том 2. - № 4. - C. 85- 93. - ISSN 2415-8453

Livinsky A.I., PhD, Associate Professor, Odessa State Agrarian University (Odessa, Ukraine)

Strategic approaches on operational management of animal enterprises in the context of their renovation

The author considers the relevance of the processes of modernization and innovative renewal of the agricultural sector in the context of the renovation development of livestock enterprises. The article defines the strategic approaches to the operational management of livestock enterprises in the context of the renovation of the industry and its role in the national economy of Ukraine. It is proved that the formalization of economic decisions in typical situations and methods of management decision-making requires a clear definition of the concepts of" unplanned production situation "and" typical situation "in relation to technological operations and processes in agricultural production. The criteria for assessing the quality of operational decisions at livestock enterprises are defined

Key words: strategic approaches, livestock enterprises, operational management

Дата надходження до редакції: 22.10 .2018 p 